\title{
SOUND RECORDINGS, WORKS FOR HIRE, AND THE TERMINATION-OF-TRANSFERS TIME BOMB ${ }^{\text {D }}$
}

\author{
by David Nimmer* and Peter S. Menell**
}

Guillaume de Machaut, the most famous composer of the Middle Ages (born 1300), gave the world Ma fin est mon commencement ("My end is my beginning"). Congress evidently had de Machaut's handiwork in mind recently when addressing the copyright status of sound recordings. For that phrase perfectly encapsulates the experience of seven centuries later: After two wrenching upheavals, we have ended up precisely back where we started. Se retrograde et einsi fin.

In particular, Congress amended the Copyright Act in 1999 to correct a "technicality" regarding whether sound recordings can qualify as specially commissioned works-for-hire. It amended the Copyright Act again, in 2000 , to undo its 1999 creation. As a result of this "millennial flipflop," 1 the issue is now left squarely indeterminate. Accordingly, the time is ripe to consider whether sound recordings can, indeed, qualify as specially commissioned works made for hire. After analyzing the issue in depth, the conclusion reached below is a resounding maybe. ${ }^{2}$

The inquiry might be of scant interest, were it not at the vortex of an impending storm. When Congress passed the current Act in 1976, it created a mechanism called termination of transfers to safeguard the interests of authors. Of particular practical significance, Congress made this termination right inalienable. Therefore, boilerplate advance assignments do not extinguish this right. ${ }^{3}$ Given the statutory details, termination largely

\footnotetext{
${ }^{\circ}(2002$ by David Nimmer and Peter S. Menell. Parts of this article derive from Release 57 to Nimmer on Copyright, (C) 2002 Matthew Bender \& Co. We thank Diane McGimsey for research assistance.

*Visiting Professor, UCLA School of Law and Of Counsel, Irell \& Manella LLP, Los Angeles, California.

**Professor of Law, University of California at Berkeley School of Law (Boalt Hall) and Executive Director, Berkeley Center for Law \& Technology.

1 Corey Field, Their Master's Voice? Recording Artists, Bright Lines, and Bowie Bonds: The Debate Over Sound Recordings as Works Made for Hire, $48 \mathrm{~J}$. Copr. Soc'Y 145, 162 (2000).

2 We are in the process of answering the many statutory and policy questions raised herein in what will necessarily be a much longer treatment. See Peter S. Menell \& David Nimmer, Defusing the Termination-of-Transfer Time Bomb (forthcoming) [hereinafter Defusing the Bomb].

3 See infra note 61.
} 
matures as a live possibility in $2003^{4}$ - a date that seemed a long way off in 1976 , but a lot closer in 1999, when the interested parties secured the amendment regarding sound recordings. Today, it is just around the corner. Because the 2000 repeal simply returns us to the status quo ante bellum, the concerns that motivated those parties have only gained added force in the interim.

This article ventilates the open questions raised by the events of 19992000 . It focuses on the positions advanced by the parties during that interval. But, as we shall see, the universe of relevant criteria exceeds what the parties themselves ventilated. In a follow-up piece, we attempt the larger task of digging into the historical circumstances by which sound recordings and albums were largely created before 1999 in order to answer those unresolved issues. ${ }^{5}$

\section{EXPOSITION}

\section{A. Works Made for Hire}

In general, the human being who creates a work of authorship owns the copyright in the product. An exception, however, arises as to works made for hire. In those instances, the hiring party, rather than the actual creator, becomes the owner of the copyright for all purposes and for all time. ${ }^{6}$

Works made for hire, in turn, fall into two categories. The first consists of works created by employees. ${ }^{7}$ Thus, to the extent that a corporation hires an individual (e.g., copywriter, embroiderer, software engineer), pays her a salary fifty-two weeks a year, supplies the tools for her to ply her craft, includes her in its health plan, provides her with IRS Form W- $2,{ }^{8}$

4 As will be explained below, that date marks the beginning of potential terminations under 17 U.S.C. $\$ 203$, although terminations under the coordinate provision of 17 U.S.C. $\S 304(\mathrm{c})$ have been possible since January 1, 1978. See infra note 65. Scattered cases have issued under the latter $\$ 304(\mathrm{c})$. See, e.g., Burroughs v. Metro-Goldwyn-Mayer, Inc., 683 F.2d 610, 621 (2d Cir. 1982) (termination of rights in Edgar Rice Burroughs' Tarzan novels); Range Road Music, Inc. v. Music Sales Corp., 76 F. Supp. 2d 375 (S.D.N.Y. 1999), reconsideration denied, 90 F. Supp. 2d 390 (S.D.N.Y. 2000) (termination of rights in songs composed by Jimmy Van Heusen in 1939).

5 See Defusing the Bomb, supra note 2.

6 See generally 1 Melville B. Nimmer \& David Nimmer, Nimmer on CopyRIGHT $\$ 5.03$ (2002).

7 Id. $\S 5.03[\mathrm{~A}]$.

8 See Eisenberg v. Advance Relocation \& Serv., Inc., 237 F.3d 111 (1st Cir. 2000) ("Eisenberg did not receive benefits such as medical insurance or vacation days, and Advance treated her as an independent contractor for tax purposes, giving her a '1090' tax form rather than a 'W-2' form, and not deducting or withholding taxes from her wages. These factors favor characterizing Eisenberg as an independent contractor."). 
directs her what services to perform, and then, when she finishes it, assigns her another task, the corporation unambiguously qualifies as the employer. ${ }^{9}$ Accordingly, the material produced by the employee belongs to the corporation by virtue of copyright's work-made-for-hire doctrine.

The second way to create a work made for hire is by specially commissioning a work. In order to be valid, the parties must agree, in a writing signed by each, that this status will pertain. In addition, not all works can so qualify. The full statutory provision defines under the for-hire rubric

a work specially ordered or commissioned for use as a contribution to a collective work, as a part of a motion picture or other audiovisual work, as a translation, as a supplementary work, as a compilation, as an instructional text, as a test, as answer material for a test, or as an atlas, if the parties expressly agree in a written instrument signed by them that the work shall be considered a work made for hire. For the purpose of the foregoing sentence, a "supplementary work" is a work prepared for publication as a secondary adjunct to a work by another author for the purpose of introducing, concluding, illustrating, explaining, revising, commenting upon, or assisting in the use of the other work, such as forewords, afterwords, pictorial illustrations, maps, charts, tables, editorial notes, musical arrangements, answer material for tests, bibliographies, appendixes, and indexes, and an "instructional text" is a literary, pictorial, or graphic work prepared for publication and with the purpose of use in systematic instructional activities. ${ }^{10}$

\section{B. Absence of Sound Recordings in 1976 Act}

The obvious candidate missing from the foregoing enumeration is "sound recordings."11 Some attribute the omission to inadvertence: The first bill incorporating the work-made-for-hire provision that was ultimately adopted stemmed from the 1960 s - before federal copyright protection commenced for sound recordings on February 15, 1972.12 Under this viewpoint, it is only an accident of history that Congress failed to in-

9 See Community for Creative Non-Violence v. Reid, 490 U.S. 730, 751-52 (1989) (detailing thirteen relevant factors, culled from Restatement (Second) of Agency).

1017 U.S.C. $\S 101$ (2000) (text prior to 1999 amendment discussed herein).

11 Another omission is computer software. But that lacuna is of scant significance. See infra note 74.

12 Act of Oct. 15, 1971, Pub. L. No. 92-140, 85 Stat. 391 (according protection effective February 15, 1972). 
clude the category of sound recordings here; it would have done so had the issue risen to the fore. ${ }^{13}$ Others draw the opposite inference: The omission in the 1976 Act must have been intentional; as to the contrary view that the pertinent compromise was worked out before federal protection for sound recordings was legislated in 1971, the problem "is the five-year period of time that was available to remedy the omission." 14

Regardless of the mental state under which it operated, Congress created the 1976 Act in such a fashion as to foreclose the possibility for commissioned status of a sound recording per se. ${ }^{15}$ When one district court nonetheless held, regarding jingles written for both television and radio, that it is "best to interpret the broad term 'audiovisual' to include both purely visual and purely audio works, as well as combined audio and visual works," the Fifth Circuit reversed that interpretation as outside the boundaries of the statute. ${ }^{16}$ Scattered district court rulings likewise have reached the unremarkable conclusion that a work cannot qualify as commissioned if the basis is that it is a sound recording. ${ }^{17}$ But those rulings stop short of pronouncing a blanket rule that something which happens to be a sound recording is ipso facto ineligible to qualify as a commissioned work. ${ }^{18}$ We return to that matter below. ${ }^{19}$

\section{1999 Amendment}

Almost two dozen years after adoption of the current Act, Congress added that missing category to the enumeration of specially commissioned works. Context is key here.

Congress adopted the Satellite Home Viewer Improvement Act of 1999 to amend the statutory licenses applicable to retransmission of television signals. ${ }^{20}$ The end of this enactment contained a provision entitled

13 See 146 Cong. Rec. S10,498 (daily ed. Oct. 12, 2000) (statement of Sen. Hatch) ("sound recordings did not obtain the status of copyrighted works until relatively recently, and when added to the list of copyrightable works was not added to the list of works made for hire").

14 Field, supra note 1, at 177.

15 As will be developed below, something that happens to be a sound recording may still be eligible as a specially commissioned work, as long as it simultaneously qualifies as one of the statutorily enumerated categories (e.g., a "supplementary work"). It may also be a work made for hire if created by a true employee.

16 Lulirama Ltd., Inc. v. Axcess Broad. Servs., Inc., 128 F.3d 872, 878 (5th Cir. 1997).

17 Ballas v. Tedesco, 41 F. Supp. 2d 531, 541 (D.N.J. 1999); Staggers v. Real Authentic Sound, 77 F. Supp. 2d 57 (D.D.C. 1999).

18 See 146 Cong. Rec. H7245 (daily ed. Sept. 6, 2000) (statement of Rep. Berman) (attempting to avoid holdings of Ballas and Staggers).

19 See Part II infra.

20 Act of Nov. 29,.1999, Pub. L. No. 106-113, app. I, 113 Stat. 1501. 
"Technical amendments." 21 That section effectuated such revisions as striking "programing" and substituting "programming."22 But the very last provision set forth there stealthily added sound recordings as a category eligible for protection as specially commissioned works made for hire. ${ }^{23}$ Obviously, that amendment had no connection to the subject matter of satellite transmissions. It was not included in prior drafts of the bill, but rather crept in at the last moment. ${ }^{24}$

The alteration itself betrays its haste. Technical amendments exist to eliminate drafting errors, and make the Copyright Act read well. The instant amendment, by contrast, does the opposite: It adds additional language to the enumeration of eligible works made for hire those produced "as a part of a motion picture or other audiovisual work, as a translation, as a supplementary work," producing the following: "as a part of a motion picture or other audiovisual work, as a sound recording, as a translation, as a supplementary work." 25 The initial lack of comma, followed later by double commas, would itself have required a later technical amendment to correct, if not for the subsequent repeal of the entire amendment.

Two months earlier, Congress had passed An Act to Make Technical Corrections to Title $17,{ }^{26}$ which actually did effectuate technical amendments to the Copyright Act. The purpose of that law was "purely technical," not to "make any substantive change in the law."27 By contrast, the instant amendment regarding sound recordings was substantive, and for that reason not technical - notwithstanding its billing. To quote Register

21 Id. sec. 1011.

22 Id. sec. 1011(a)(1).

23 The Satellite Home Viewer Improvement Act of 1999 forms part of the Intellectual Property and Communications Omnibus Reform Act of 1999. Buried toward the end of that law is another feature, likewise denominated "technical amendments," which likewise actually exerts substantive impact. Act of Nov. 29, 1999, Pub. L. No. 106-113, app. I, sec. 5005, 113 Stat. 1501. See David Nimmer, Appreciating Legislative History, 23 CARdozo L. Rev. 909, 931-32 (2002).

24 The bill was cleared for the White House on November 19, 1999. On November 9, the subject language appeared in the Conference Report for the Intellectual Property and Communications Omnibus Reform Act of 1999. See H.R. REP. No. 106-464 (1999). It was carried forward from there to the Conference Report for the larger bill allocating moneys to the District of Columbia (into which the Omnibus Intellectual Property bill was consolidated.). See H.R. REP. No. 106-479, at 1113 (1999).

2517 U.S.C. $\$ 101$ (2000).

26 Act of Aug. 5, 1999, Pub. L. No. 106-44, 113 Stat. 221.

27 H.R. REP. No. 106-84, at 1 (1999). 
of Copyrights Marybeth Peters, "this was a substantive amendment to the law, not a technical amendment as some have claimed."28

When the lobbyists' backroom handiwork became known, a firestorm of criticism ensued. Recording artists and their representatives expressed outrage that the major record labels would attempt to effectuate such changes secretly and that Congress would accede to such changes without soliciting the views of recording artists. ${ }^{29}$ Although Congress believed at enactment that the amendment "was a non-controversial technical change that merely clarified current law," 30 it later had to concede that "serious debate" 31 renders the matter "not uncontroversial." 32 The House Subcommittee on Courts and Intellectual Property accordingly convened a hearing on the subject a half-year after the amendment had taken effect. Many expressions of Congressional contrition punctuated the hearings ${ }^{33}$ (e.g., "we should never do business that way"). ${ }^{34}$

In convening that 2000 Oversight Hearing, the Chair noted that from the time that sound recordings were first accorded protection in 1972, record companies had been registering them as works made for hire. Rep. Coble further noted that record companies have "inserted boilerplate language in all recording contracts which specified that the sound recordings

28 United States Copyright Office and Sound Recordings as Work Made for Hire: Hearing Before the Subcommittee on Courts and Intellectual Property of the House Committee on the Judiciary, $106^{\text {th }}$ Cong. 34 (2000) [hereinafter 2000 Hearings].

29 See Eric Boehlert, Four Little Words: How the Record Industry Used a Tiny Legislative Amendment to Try to Steal Recording Copyrights from Artists Forever, SAlon.com, Aug. 28, 2000 ("'It was very sinister at its root,' says former Eagles leader Don Henley. 'We never should have had to go through this. But the RIAA thought they had enough clout in Congress to make it stick. And they almost did."'); Brooks Boliek, New Music Biz Discord Over 'Work for Hire' Status RIAA Comes Under Fire for Copyright Revisions, Hollywood ReP., May 23, 2000, at 8 ("Recording artists and their managers think the Recording Industry Association of America pulled a fast one last year when the change was slipped into the Satellite Home Viewer Improvement Act. . . . Artists from Don Henley to Coolio have lined up to oppose the change. They feel that the change and the manner in which it was carried out, without a hearing or testimony on the subject, was an effort to undo their rights.").

30146 Cong. Rec. H7245 (daily ed. Sept. 6, 2000) (statement of Rep. Berman). 31 Id.

32146 Cong. Rec. S10,498 (daily ed. Oct. 12, 2000) (statement of Sen. Hatch).

33 See 146 CoNG. Rec. H7245 (daily ed. Sept. 6, 2000) (statement of Rep. Berman) ("Congress should have undertaken more extensive deliberations before making this change").

34146 CoNG. REC. H7772 (daily ed. Sept. 19, 2000) (statement of Rep. Conyers). 
were works for hire." 35 To this must be added that other boilerplate also typically attends agreements between recording artists and their labels: "These contracts also typically state that if a court of law finds particular works not to be 'for hire' as stipulated by the copyright law, then the works are considered to be assigned to the record company. This type of clause has almost invariably been non-negotiable."36

Moreover, Rep. Coble maintained that no registration at the U.S. Copyright Office "has ever been challenged on the basis that a sound recording does not qualify as a work made for hire." $37 \mathrm{He}$ concluded, as had the Conference Committee that deliberated the Satellite Home Viewer Improvement Act of 1999, that this amendment represented a "technical and conforming change to the definition of a "work made for hire." 38

The Register of Copyrights defused those observations. Whereas record companies of the 1960s had employed backup singers and engineers, meaning that works of that vintage might have truly qualified as being made for hire, over the decades the record companies' level of involvement has diminished "so that now, in many cases, record companies simply provide funds at the 'front-end,' and distribution at the 'back-end' of a sound recording's production." 39 Accordingly, sound recordings typically no longer qualify as works by employees. An additional reason that the practice from 1972 onwards is unilluminating is that Congress amended the strictures applicable to works made for hire effective January 1, 1978. ${ }^{40}$ To the extent that record companies adopted an efficacious methodology as of 1972 and simply continued it unaltered, the question remains open whether that practice achieved the desired effect after the 1976 Act went into effect.

As to the instant question whether sound recordings qualified before the 1999 amendment as specially commissioned works, the Register aptly noted that neither industry contracts nor registration practices at the Cop-

35 Memorandum from Howard Coble to Members of the Subcommittee, May 23, 2000. See 2000 Hearings, supra note 28 , at 47 (statement of Register Peters) ("all featured artists, except a very few, sign these work made for hire agreements").

362000 Hearings, supra note 28, at 78 (statement of Michael Greene). See id. at 48 (statement of Register Peters); 146 Cong. Rec. S10,498 (daily ed. Oct. 12, 2000) (statement of Sen. Hatch).

37 Coble Memorandum, supra note 35.

38 Id. See H.R. REP. No. 106-464, at 105 (1999). "Sound recordings have been registered in the Copyright Office as works made for hire since being protected in their own right." Id. at 106.

392000 Hearings, supra note 28 , at 39.

40 The two categories of works made for hire discussed in Part I[A] supra find expression in the current Act in 17 U.S.C. $\$ 101$. The face of the prior law, the 1909 Act, drew no such distinction. 
yright Office could make them so - the inquiry instead is whether they qualified under the terms of the statute. It is that question that is joined below. ${ }^{41}$

\section{2000 Repeal}

The groundswell of outrage following publicity regarding the foregoing amendment, as well as record companies' desire to smooth over any rifts with recording artists at a critical juncture in their epic battle to stop Napster, brought about swift repeal. ${ }^{42}$ Congressional hearings in May 2000 surfaced the complex issues underlying the insertion of four words "as a sound recording" - into the definition of a "work made for hire." By August 8, 2000, the Recording Industry Association of America and several artist groups agreed to submit a recommendation to Congress asking that the "technical amendment" be rescinded. The Work Made for Hire and Copyright Corrections Act of $2000^{43}$ deleted "sound recordings" from the enumeration of eligible commissioned works. ${ }^{44}$ It also added that in "determining whether any work is eligible to be considered a work made for hire," neither the 1999 amendment, "nor the deletion of the words added by that amendment . . . shall be considered or otherwise given any legal significance." 45 Wishing to avoid any imputation that the repeal itself connoted a substantive choice of policy, ${ }^{46}$ Congress expressed itself as neutrally as possible ${ }^{47}$ - albeit that the actual language employed here is more than "slightly awkward in its legislative construction,"48 perhaps as an artifact that "this compromise was not easily reached." 49

As a consequence of this amendment, the statutory provision regarding commissioned works is to be interpreted as if both the 1999 amendment and its 2000 repeal "were never enacted, and without regard to any inaction or awareness by the Congress at any time of any judicial determi-

41 See Part II infra.

42 See A\&M Records, Inc. v. Napster, Inc., 239 F.3d 1004 (9th Cir. 2001).

43 Pub. L. No. 106-379, sec. 1, 114 Stat. 1444 (Oct. 27, 2000).

44 Id., sec. 2(a)(1).

4517 U.S.C. $\S 101$ (2000) (definition of "work made for hire," I 2(A)). That admonition applies to both "the courts and the Copyright Office." Id.

46 See H.R. ReP. No. 106-861, at 5 (2000); 146 Cong. Rec. H7245 (daily ed. Sept. 6,2000 ) (statement of Rep. Berman).

47 Moving from the provision cited supra in note 45 , its coordinate clause commands that the sequence of passage and repeal not "be interpreted to indicate congressional approval or disapproval of, or acquiescence in, any judicial determination." 17 U.S.C. $\$ 101$, definition of "work made for hire," II 2(B).

48146 Cong. Rec. H7772 (daily ed. Sept. 19, 2000) (statement of Rep. Conyers).

49146 Cong. Rec. H7244 (daily ed. Sept. 6, 2000) (statement of Rep. Coble). 
nations." 50 As stated in the legislative history, the purpose "is to restore the status quo as it existed before November $29,1999 \ldots$ and to do so in a manner that does not prejudice any person or entity that might have interests concerning this question." 51

\section{E. Timing of Amendment and Repeal}

The Satellite Home Viewer Improvement Act of 1999 explicitly provided that its "technical amendments" took effect only on enactment rather than retroactively.52 That provision was hardly inadvertent, inasmuch as other provisions of the same law were explicitly given retroactive application. ${ }^{53}$ (For those who follow music copyright issues in Congress, the situation here obviously differs markedly from the "La Cienega amendment," 54 which by its terms is directed at conduct that took place "before January 1, 1978.") 55

As a result of how it was crafted, the 1999 Amendment (even had it not been later repealed) would have exerted no impact on pre-existing sound recording. In any event, the Work Made for Hire and Copyright Corrections Act of 2000 made its repeal retroactive ${ }^{56}$ as of the effective date of the 1999 Act. $^{57}$ The purpose, of course, was to restore the status quo ante. ${ }^{58}$

5017 U.S.C. $\$ 101$ (2000) (definition of "work made for hire").

51 H.R. ReP. No. 106-861, at 1 (2000).

52 Act of Nov. 29, 1999, Pub. L. No. 106-113, app. I, sec. 1012, 113 Stat. 1501. See 2000 Hearings, supra note 28, at 45 (statement of Register Peters).

53 See Act of Nov. 29, 1999, Pub. L. No. 106-113, app. I, sec. 1012, 113 Stat. 1501.

54 La Cienega Music Co. v. ZZ Top, 44 F.3d 813 (1995), held that a pre-1978 distribution of phonograph records without proper copyright notice forfeited rights in the musical compositions embodied therein. After the Supreme Court denied certiorari, 516 U.S. 927 (1995), the industry persuaded Congress to "reverse" the Ninth Circuit's decision retroactively, effectively restoring copyright in musical compositions released on phonorecords lacking proper copyright notice. See Pub. L. No. 105-80, 111 Stat. 1534 (1997); 17 U.S.C. $\$ 303($ b) (2000) ("distribution before January 1, 1978, of a phonorecord shall not for any purpose constitute a publication of the musical work embodied therein")." See generally 1 NIMMER \& NiMMER, supra note $6, \S 4.05[\mathrm{~B}][7]$.

55 Act of Nov. 13, 1997, Pub. L. No. 105-80, sec. 11, 111 Stat. 1529.

56 See 146 Cong. Rec. H7246 (daily ed. Sept. 6, 2000) (statement of Rep. Berman) ("confusion and injustice ... would otherwise result").

57 Pub. L. No. 106-379, sec. 2(b)(1), 114 Stat. 1444 (Oct. 27, 2000).

58 H.R. REP. No. 106-861, at 2 (2000). The legislation also contains a severability clause, in the event that such retroactive application were to be held unconstitutional. Pub. L. No. 106-379, sec. 2(b)(2), 114 Stat. 1444 (Oct. 27, 2000). See H.R. Rep. No. 106-861, at 5 (2000); 146 Cong. Rec. H7246 (daily ed. Sept. 6, 2000) (statement of Rep. Berman). 


\section{EVALUATION}

As previously noted, virtually all contracts that artists signed with record companies from 1972 onwards have contained (1) an acknowledgement that the contribution constitutes a work made for hire, and (2) in case that characterization fails, a backup assignment. ${ }^{59}$ Thus, regardless of the vitality of the for-hire theory, the record companies have owned the sound recordings in any event.

To take an example, consider Alanis Morissette's Jagged Little Pill, a 1995 album containing thirteen songs released under the Warner label. Assuming that its production conformed to industry norms, Morrissette signed the boilerplate regarding both for-hire status and an assignment. Therefore, Warner has owned the album either as its "author" under the former theory or as assignee of the author under the latter. Either way, Warner Records is the owner and has been since the album's inception. So why all the brouhaha?

\section{A. Termination of Transfers}

Only one salient difference separates owning something via assignment from owning it as a work made for hire: The latter continues for the life of the copyright, whereas the former is subject to statutory termination of transfers. ${ }^{60}$ What makes this difference of practical significance is that Congress made the termination right inalienable. ${ }^{61}$ Therefore, record companies cannot simply require that this right be assigned with all of the other sticks in the copyright bundle.

The distinction between ownership by way of assignment and through copyright's work-made-for-hire doctrine is not inevitable in every instance. Despite assumptions to the contrary, termination does not arise "automatically." 62 Instead, it requires affirmative action. ${ }^{63}$ That affirmative decision to terminate potentially arises as to works created in 1978

59 See Part I[C] supra.

60146 CONG. REC. H7774 (daily ed. Sept. 19, 2000) (statement of Rep. JacksonLee). See 3 Nimmer \& Nimmer, supra note 6, ch. 11.

61 "Termination of the grant may be effected notwithstanding any agreement to the contrary, including an agreement to make a will or to make any future grant." 17 U.S.C. \& 203(a)(5) (2000). The one partial exception to advance inalienability is that "an agreement for . . . a further grant may be made ... after the notice of termination has been served." Id. § 203(b)(4). But that further grant can be made only to the one entity whose rights would otherwise be terminated. Id. The earliest that that further grant could be made is after the passage of twenty-five years. See 3 Nimmer \& Nimmer, supra note $6, \S 11.08[\mathrm{~A}]$.

62 See 146 Cong. REC. H7773 (daily ed. Sept. 19, 2000) (statement of Rep. McCarthy).

63 See 3 Nimmer \& Nimmer, supra note 6, § 11.06 . 
and thereafter. (As to sound recordings created when Congress first accorded them protection in 1972, they are governed by the 1909 Act. Because those works fall outside the 1976 Act strictures with respect to the special requirements for commissioned works, they can qualify as works made for hire for the reasons outlined by Register Peters, ${ }^{64}$ regardless of the matters addressed in the 1999 amendment and its 2000 repeal. Accordingly, the balance of this article treats those works no further. ${ }^{65}$ As to those works, the first termination opportunity arises after thirty-five years. Thus, the question whether Jagged Little Pill is subject to termination will ripen in 2030.

Given that the first recordings created during the pendency of the current Act date from 1978, the thirty-five-year termination window commences in 2013.66 Because a termination notice may be sent ten years before its effective date, the first valid notice could be served as early as 2003.67 The first terminations under the 1978 Act are accordingly just around the corner - but only on the assumption that the subject works failed to have been produced for hire. ${ }^{68}$ This timing explains why only scattered cases to date have even addressed the status of sound recordings as specially commissioned works for hire. ${ }^{69}$ The issue simply has not become timely yet - and will not until next year rolls around.

The question thus remains unaddressed by jurisprudence to date whether sound recordings created in 1978 and thereafter can qualify as works made for hire. Of course, to the extent that a record company or any other entity hired employee musicians, producers, singers, engineers, etc., to create a sound recording ${ }^{70}$ the resulting product would qualify as a work made for hire independent of the matter currently under discus-

64 See text accompanying supra note 39.

65 It should be noted that works created during the pendency of the 1909 Act are also subject to termination of transfers, albeit on a different time-line from the one applicable to works created in 1978 and thereafter. Compare 17 U.S.C. \$ 203 with 17 U.S.C. \$ 304(c). But under both schemes, works made for hire are ineligible for termination. 17 U.S.C. $\$ \S 203(a), 304$ (c) (2000). For current purposes, it is assumed that sound recordings created during the pendency of the 1909 Act could qualify under the relaxed work-made-forhire strictures then applicable. The question underlying this article is whether sound recordings can qualify as works made for hire under the more exacting terms of the 1976 Act's definition of "specially commissioned works for hire."

662000 Hearings, supra note 28, at 7. See 3 Nimmer \& Nimmer, supra note 6 , $\S 11.05[\mathrm{~B}][1]$.

67 See id. $\S 11.06[\mathrm{~A}]$.

68 See id. \$ 11.02[A][2].

69 See Part I[B] supra.

70 What of a "mixed" work created by an employee engineer but independent contractor singer? See infra note 132. 
sion. ${ }^{71}$ Thus, more particularly the question under examination here is whether sound recordings created in 1978 and thereafter can qualify as specially commissioned works for hire.

\section{B. Shoehorning Sound Recordings Into Other Categories}

Given that the statute creates nine categories of works that can be eligible to qualify as specially commissioned works for hire, ${ }^{72}$ from which enumeration "sound recordings" are conspicuously absent, ${ }^{73}$ the question boils down to whether sound recordings could so qualify, despite not being enumerated. ${ }^{74}$ In this regard, it would seem that the lack of enumeration in the 1976 Act does not command a categorical disqualification from commissioned status for anything that happens to be a sound recording. It simply means that for that work to qualify, it must be shoe-horned within one of the other categories.

For instance, to the extent that a children's book company produced a sound recording as a parent's guide, ${ }^{75}$ it could own the product as a "supplementary work" (assuming also the requisite signed writing). The issue

71 See Part I[A] supra. Loose statement to the contrary in the committee report should be discounted. See, e.g., H.R. Rep. No. 106-861, at 4 (2000) (purpose of repeal is to "amend copyright law so that employers would no longer automatically own the copyrights to audio recordings created by employees as part of their jobs") (to the contrary, employers would continue to automatically own recordings created by employees as part of their job).

72 The statute applies to "a work specially ordered or commissioned for use as [1] a contribution to a collective work, [2] as a part of a motion picture or other audiovisual work, [3] as a translation, [4] as a supplementary work, [5] as a compilation, [6] as an instructional text, [7] as a test, [8] as answer material for a test, or [9] as an atlas." See Part I[A] supra.

73 See Part I[B] supra.

74 A similar question could arise as to other non-enumerated categories, such as software. See supra note 11 . There are several reasons why that inquiry is far less pointed than the instant analysis vis-à-vis sound recordings. First, audiovisual works are one category of specially commissioned works. See part I[A] supra. In an era of multimedia, it is often possible to shoehorn a piece of software into that category. Second, software virtually never has the long shelf life of certain sound recordings, such that its exploitation remains of vital interest after the passage of thirty-five years. See Matthew R. Harris, Note, Copyright, Computer Software, and Work Made for Hire, 89 MicH. L. REv. 661, 687 (1990) ("The right to terminate an assignment, however, is virtually worthless in the software industry. Software has a relatively short market life; in general, most software is obsolete within ten years of its creation.").

75 Cf. SmithKline Beecham Consumer Healthcare, L.P. v. Watson Pharms., Inc., 211 F.3d 21, 23 (2d Cir.), cert. denied, 531 U.S. 872 (2000) (audio tape on how to quit smoking used as guide to nicotine patch). 
thus reduces to whether sound recordings created from 1978 and onwards in fact fell within the nine categories enumerated in the 1976 Act.

Witnesses at the 2000 Oversight Hearing contested that point bitterly. Sheryl Crow testified that recording artists no more work for record companies than do novelists for publishers. ${ }^{76}$ She gilded that lily by observing several times that she, not the record company, pays for the recording and production of her albums: "I must also decide what musicians I want to perform on each song, given the desired sound I want to attain, what engineering staff to implement my sonic vision, what studio will be appropriate (in my situation, I own my recording equipment which is set up in my home studio), and how much I want to spend."77

Turning to the nine discrete statutory categories, the nub of the dispute concerned "contribution to a collective work."78 One copyright professor testified that a single artist's album was not a "collective work"; 79 in her view, only the combination of numerous individuals' efforts, such as a "Christmas album involving different artists, would fall under the 'collective works' category." 80 But another testified on behalf of the Recording Industry Association of America that because the "contribution of an individual sound recording as one of several selections on a CD or other album" will typically qualify on this basis, the amendment did "not substantially change current work for hire law or allocations of rights." 81 Neither of those characterizations captures the full complexity of the issue.

762000 Hearings, supra note 28 , at 79 .

$77 \mathrm{Id}$. at 73. See id. at 75 ("every penny the record label spends on behalf of the artist . . . is 100 percent recoupable") (statement of Michael Greene).

78 The statute defines "collective work" as "a work, such as a periodical issue, anthology, or encyclopedia, in which a number of contributions, constituting separate and independent works in themselves, are assembled into a collective whole." 17 U.S.C. $\$ 101$ (2000).

792000 Hearings, supra note 28, at 68 (statement of Marci Hamilton).

$80 \mathrm{Id}$. As of early deliberation of the 1976 Act, the notion was widespread that a "collective work" required multiple authors - a status about which one witness complained. See House Comm. on the Judiciary, $88^{\text {Th }}$ Cong., Copyright law Revision, Part 3: Preliminary Draft for Revised U.S. Copyright Law and Discussions and Comments on the Draft 265 (Comm. Print 1964) ("I also wondered why, in the definition of 'collective work,' there's a need to say that a 'collective work' combines 'the separate contributions of various authors into a collective whole.' Some very good collections are the works of a single author, and I would like that gone into."). But by the time the authoritative legislative history was compiled, it contemplated, "Examples of 'collective works' would ordinarily include ... collections of the discrete writings of the same authors." H.R. REP. No. 941476 , at 122 (1976). The question under that language thus becomes when writings are discrete.

812000 Hearings, supra note 28, at 61 (statement of Paul Goldstein). 


\section{Did the Amendment Change "Allocation of Rights"?}

The first RIAA claim is that the 1999 amendment did not substantially change allocation of rights. On the surface, the claim is hard to swallow - it seems overwhelmingly likely that both industry and Congress spent a "huge amount of time" 82 on the repeal not in order to achieve intellectual order in the framing of Title 17 of the United States Code, but instead because actual interests were at stake. A bit of examination validates that suspicion.

Because the 1999 amendment applied only to sound recordings produced after its effective date, ${ }^{83}$ it is instructive to contrast a hypothetical sound recording to be produced in 2010 with one from, say, 1980. As to the 1980 recording, the primary basis that it could have qualified as a work made for hire was the claim that it may have constituted part of a collective work. ${ }^{84}$ Because the 1999 amendment prospectively dispensed with that limitation, the 2010 recording is ipso facto eligible to be a specially commissioned works for hire, regardless of any collection to which it may (or may not) contribute.

The distinction is key - and came just in the nick of time for the record companies. In a future world of digital phonorecord delivery, ${ }^{85}$ the old-fashioned notion of a thirteen-song "album" becomes anachronistic. ${ }^{86}$ "[N]ew Internet-based technologies that allow the consumer to download individual selections have brought about a sea-change in the very concept of what a sound recording is." ${ }^{.77}$ As of 2010 , there may be no basis to argue that individually prepared songs qualify as a "contribution to a collective work." 88 Gauged by pre-1999 law, they would be ineligible as specially commissioned works for hire; gauged by 1999 law, however, they are fully eligible. For this reason alone, the 2000 repeal, by reallocating rights pro-

82146 Cong. Rec. H7774 (daily ed. Sept. 19, 2000) (statement of Rep. Berman).

83 See Part I[E] supra.

84 It is also possible that the 1980 recording could qualify as a "compilation," but the ownership implications are precisely the same. See Part I[A] supra. Therefore, we focus here on the more likely claim that a sound recording would constitute a "contribution to a collective work."

85 See 2 Nimmer \& Nimmer, supra note $6, \S 8.23$.

86 In the future, moreover, why should performers be limited to cutting a 12-song "album" or releasing a three-disc "boxed set," both of which are simply throwbacks to the time when delivery of recorded music was constrained by physical media? Singers of the future might simply direct 7 hours, or 70, of musical delight however they wish.

2 NimMer \& Nimmer, supra note 6, § 8.21[A] n.28.

872000 Hearings, supra note 28, at 15 (statement of Rep. Delahunt) (emphasis original).

88 See id. at 45 (statement of Register Peters). 
spectively, ${ }^{89}$ changes the face of copyright law. ${ }^{90}$ Indeed, counsel for the RIAA, looking to a "singles market on the Internet," admitted at the hearings that this prospective-only amendment would work "a substantive change for the future."91

As to the first claim, therefore, the professor who testified on behalf of the RIAA would seem to have been in error. ${ }^{92}$

\section{Did the Amendment Change "Current Work for Hire Law"?}

The second RIAA claim is that the 1999 amendment did not substantially change current work for hire law. We have already seen that songs created in the future era of digital phonorecord delivery would qualify as works made for hire under the regime of the 1999 amendment. ${ }^{93}$ That status would represent no substantial change only if pre-1999 recordings also qualified routinely as works made for hire. It is that status that therefore demands attention.

To bolster its claim, the RIAA posited that the "contribution of an individual sound recording as one of several selections on a $\mathrm{CD}$ or other album" meets the statutory definition of being a "contribution to a collective work." 94 Is that characterization accurate?95

89 In other words, had the 1999 amendment remained in force, it would have exerted real, not technical, force as to subsequently created sound recordings.

90 The RIAA's defense of the 1999 amendment is that it was technical because previously created sound recordings qualified as commissioned works on other bases. That proposition misses the mark, given that the 1999 amendment failed to affect pre-existing sound recordings. Instead, as explained above, its application was solely prospective. See Part I[E] supra.

912000 Hearings, supra note 28, at 88 (statement of Cary Sherman). Cf. 146 CoNG. ReC. H7772 (daily ed. Sept. 19, 2000) (statement of Rep. Conyers) ("digital era lends to creators great opportunities for marketing their works of authorship").

92 See supra text accompanying note 81.

93 See Part II[B][1] supra.

94 See text accompanying supra note 81.

95 The legislative history for the 1976 Act is unhelpful here. That language was embodied as a compromise definition in the 1965 Revision Bill; but it was not specifically discussed in the Reports before its introduction. The Reports provide no explanation why particular categories were included. See House Comm. on the Judiciary, $89^{\text {th }}$ Cong., Copyright Law Revision, Part 6: Supplementary Report of THE Register of Copyrights ON the General Revision of the U.S. Copyright Law: 1965 Revision BILL 67 (Comm. Print 1965) (including under the works made for hire prong "a work specially ordered or commissioned for use as a contribution to a collective work, as part of a motion picture, as a translation, or as a supplementary work"). 
The case law, albeit sparse, is uniform in denying commissioned status to a sound recording per se. ${ }^{96}$ Indeed, it could not be otherwise, given the absence of that category from the statute. But the question remains whether an individual sound recording at issue in a particular case might qualify as a contribution to a collective work. Commentary runs the gamut - it is said that sound recordings "always, usually, sometimes, or never fall within" the pre-existing category. ${ }^{97}$ The extreme claims may be discounted: The Christmas album invoked above satisfies the prerequisites of being a contribution to a collective work; conversely, a keyboardist who puts out an album consisting of his solo rendition of Beethoven's Fifth Symphony or Richard Strauss' Ein Heldenleben ${ }^{98}$ has not produced a "collective work" under any theory. ${ }^{99}$

The remaining possibilities are occasionally, sometimes, or often. "It could very well be that the courts will find, when they start ruling on these cases, that in 2013 some sound recordings are works made for hire and other sound recordings aren't works made for hire and some sound recordings are contributions to a collective works or a compilation and others aren't." 100

Here, an empirical question arises: A myriad of circumstances undoubtedly underlay production of sound recordings from 1978 through 1999. As Senator Hatch explains, "the facts can vary so widely - some albums are primarily the product of the producer, some of one artist, some of a group."101 To that consideration must be added innumerable other circumstances that could incline towards, or detract from, the characterization of any given album released since 1978 as a collective work. For instance, an album containing a continuous "story line" of newly-composed

96 See Part I[B] supra.

97146 CoNG. Rec. H7245 (daily ed. Sept. 6, 2000) (statement of Rep. Berman).

98 That score is through-composed, i.e., it contains no rests. Accordingly, it is impossible to say that it consists of the combination of various individual "works" - even if such a dubious claim were entertained as to the four movements of Beethoven's Fifth Symphony.

99 It should be recalled that the prerequisite for a collective work is that it comprise "separate and independent works in themselves" - a status lacking as to the recordings posited above. See supra note 78.

1002000 Hearings, supra note 28, at 43 (statement of Rep. Berman).

101146 Cong. Rec. S10,498 (daily ed. Oct. 12, 2000) (statement of Sen. Hatch). 
music $^{102}$ would seem no more a collective work than a novel ${ }^{103}$ consisting of various chapters. 104

To answer that empirical question would require examination of not only the foregoing factors, but numerous others: What about an album resulting from the efforts of bona fide employees of record labels as sound engineers? Or from the use of backup vocalists and musicians who were bona fide employees of the featured artist? ${ }^{105}$ What happens if an album registered as a commissioned work made for hire was produced without any advance agreement between record company and artist as to its status? ${ }^{106}$ Or even if with advance agreement, if the performers entered the studio before that agreement was documented in writing? ${ }^{107}$ Even after all those circumstances are sorted out, new questions will arise regarding "singles." 108 The permutations are endless. As the Register of Copyrights testified, the answer "is going to depend on the facts of the putting of an album together." 109

In light of that profusion of possibilities, the empirical claim that pre1999 sound recordings, as a factual matter, routinely qualified as contributions to collective works seems like rank speculation. Until painstaking analysis is performed, the matter remains in doubt. Because there is no armchair answer to this matter, the RIAA's second claim therefore cannot be accepted at face value. ${ }^{110}$

\section{B. Sorting Out the Consequences}

Today, after the millennial flip-flop, the controversy over potential termination of transfers in sound recordings remains live. ${ }^{111}$ If courts ruling on the issue starting in $2003^{112}$ conclude that the sound recordings

102 That continuous story line negates the existence of "separate and independent works in themselves." See supra note 78.

103 An anthology of works by a single author first published at different times presumably qualifies as a collective work. See supra note 80 . By contrast, even if an author takes twenty years to write her first novel, the product does not so qualify. See 1 Nimmer \& Nimmer, supra note $6, \S 3.02$.

104 See 2000 Hearings, supra note 28 , at 81,82 (" 12 or 13 songs, which I look at as chapters") (statement of Sheryl Crow).

105 See Part II[D] infra.

106 See Playboy Enters., Inc. v. Dumas, 53 F.3d 549 (2d Cir. 1995), cert. denied, 516 U.S. 1010 (1995).

107 See Schiller \& Schmidt, Inc. v. Nordisco Corp., 969 F.2d 410 (7th Cir. 1992).

108 The question arises whether the "single" was a collective work, which in turn leads to the inquiry whether it was combined with another song on the flip side, or instead was truly a single (such as Don McLean's American Pie).

1092000 Hearings, supra note 28, at 45 (statement of Register Peters).

110 See supra text accompanying note 81 .

111 H.R. REP. No. 106-861, at 2 (2000).

112 See Part I[E] supra. 
there in issue qualify as contributions to collective works (or in one of the other categories), no termination will arise. ${ }^{113}$ Otherwise, termination will be permitted.

The latter result represents the goal of the recording artists in obtaining the 2000 repeal of the 1999 amendment. Nonetheless, it remains open to question whether that result will occur. To the extent that individual sound recordings are ruled to fall outside the work-made-for-hire framework, then all authors are eligible to terminate their assignments to the record companies. It is that outcome on which the Sheryl Crows and Bruce Springsteens ${ }^{114}$ of the world are banking. ${ }^{115}$ But the upshot of that ruling would seem to apply more broadly than to those featured artists. Producers, backup musicians, sound engineers, and others might also have a right to terminate, which could produce chaos in the exploitation of sound recordings. ${ }^{116}$

The result at that juncture could be even less beneficial to a Crow or Springsteen. Imagine that their contracts entitle them to $10 \%$ of the record label's receipts. ${ }^{117}$ Thinking that sum paltry, they terminate and thereby reclaim the copyright. But within the notice of termination window, ${ }^{118}$ the two producers, three sound engineers, eight backup musicians, and six nonfeatured vocalists have a similar brainstorm. At that point, the claimants to the work have jumped to twenty.

$\overline{113}$ The assumption here is that all other legal pre-requisites are satisfied, such as a writing signed by both parties.

114 Note that Ms. Crow introduced into evidence letters from Mr. Springsteen, the Dixie Chicks, and many others. 2000 Hearings, supra note 28, at 70.

115 See 146 Cong. Rec. S10,498 (daily ed. Oct. 12, 2000) (statement of Sen. Hatch) (recording artists believe work-made-for-hire provisions of their contracts to be unenforceable).

1162000 Hearings, supra note 28, at 40 (statement of Register Peters) ("There could easily be a dozen or more potential co-authors of a single sound recording.").

117 Though the Congressional record contains references to "royalty contracts," 2000 Hearings, supra note 28 , at 46 , the actual figure invoked above is strictly hypothetical. For a detailed account of the range of royalties typically offered to performing artists of differing stature by the major record labels, see Donald S. Passman, All You Need to Know About the Music Business 105-15 (4th ed. 2000).

118 Even though the termination window lasts for only five years (from year 25 to year 40 following the grant, 17 U.S.C. $\$ 203(a)(3)$ ), an assignor seeking to terminate must serve an "advance notice" "not less than two or more than ten years" prior to the termination date, 17 U.S.C. $\S 203(\mathrm{a})(4)(A)(2000)$. Therefore, the notice of termination window runs from twenty-five years following the grant (ten years in advance of year 35) until thirty-eight years following the grant ("not less than two" years from the end of the termination window (year 40 following the grant)). See generally 3 NiMMER \& NIMMER, supra note $6, \S 11.06[\mathrm{~A}]$. 
Even taking as a given that Sheryl Crow contributed more to the album's success than did her drummer and recording engineer, the result does not necessarily follow that she is entitled to a greater share. Rather, hornbook law holds that joint authors who labor absent an agreed allocation of their rights share equally in the product. ${ }^{119}$ As counter-intuitive as it might seem, the upshot is that the other nineteen newfound authors can each elbow for his proportionate share, thus reducing Crow's interest to one-twentieth, i.e., 5\%. ${ }^{120}$ Each of the erstwhile nineteen co-owners could issue their own non-exclusive licenses to exploit the work - even over Crow's explicit objections! ${ }^{121}$ A savvy weighing of interests would counsel those in the role of Crow and Springsteen to simply continue the 10\% stance and not to terminate at all. ${ }^{122}$

To remedy that imbroglio, the Copyright Office suggested a solution at the Oversight Hearing that was convened after the 1999 amendment. The Office recommended a copyright amendment limiting termination rights to "key contributors." If implemented, the Sheryl Crows and Bruce Springsteens of the world would be able to terminate their assignments, while the raft of minor players would be left without a second bite at the remuneration apple. But even this proposal would have engendered controversy. Which Rolling Stones would qualify as "featured artists"? Does it depend on who penned the composition? Furthermore, producers often play a critical role in the creation of many sound recordings. ${ }^{123}$ The Office proposal would reduce the number of serious contenders, but the possibility of holdouts remains even when the number of claimants has been reduced all the way down to two.

Predictably, the RIAA objected to the Copyright Office's fix: "that particular cure is worse than the disease, pitting creator against creator.

119 See id. $\$ 6.08$. There is a dearth of case law on point. See id. It therefore remains open to question whether there could be an agreement to the contrary that is not in writing or one that was "implicit" under the circumstances. Many circumstances could render this field ripe for litigation.

120 For a contrary proposal, see F. Jay Dougherty, Not a Spike Lee Joint? Issues in the Authorship of Motion Pictures Under U.S. Copyright Law, 49 UCLA. L. REV. 225 (2001).

121 See 3 NimMER \& Nimmer, supra note $6, \S 6.10$.

122 The worst of all worlds for Crow and Bruce Springsteen would arise if everyone terminated except for them - leaving them with only $10 \%$ of the remaining $5 \%$ share left in the hands of the record label!

123 See generally M. William Krasilovsky \& Sidney Shemel, This Business of Music $37-38$ ( $8^{\text {th }}$ ed. 2000) (noting rise of the independent producer); Reebee Garofalo, Rockin' Out: Popular Music in the USA 288-89 (2d ed. 2002) (characterizing George Martin; the Beatles' longtime producer, as "the fifth Beatle"); Eric Olsen et al., The EnCyClopedia of RECORd Producers 214 (1999) (profiling careers and roles of leading record producers). 
*** Who is to decide who are the 'lesser' contributors?"124 In reply the National Academy of Recording Arts \& Sciences maintained on behalf of recording artists that the RIAA"s objection "is merely confetti being tossed into the air to hide reality" on the basis that "side musicians, backup singers and engineers, are hired to work on a song with the contractual understanding through standard industry agreements that their contributions are made without claims of authorship."125

There are two ways to take that last objection. If featured artists actually employ backup musicians and singers, then that characterization is eminently justifiable. Not only have both Bruce Springsteen and Prince registered their recordings listing themselves as employers, ${ }^{126}$ but there was also testimony at the Hearing that Clarence Clemens worked as a salaried employee on behalf of Springsteen, and that his union membership so entails. ${ }^{127}$ To the extent accurate and representative, then it may be the case that the problem of backup singers and musicians will never mature.

On the other hand, if the claim is founded solely on "standard industry agreements" absent such employment, then it misses the mark. For if such agreements can prevent background artists from terminating, then why are the featured artists allowed to ignore their own contracts with the record industry, which likewise bar such terminations? ${ }^{128}$ Sauce for the gander would appear to cook their goose.

It is not enough to maintain, as did one witness who testified against the 1999 amendment, "Many of those working for the featured artist would have been considered employees of the featured artists (and therefore their creative contributions belonged to the featured artist as author), assigned all rights, or agreed that their contribution was a work made for hire." 129 The italicized proposition would seem to correspond to a backup musician who agreed that his contribution to a sound recording would be a commissioned work on behalf of, say, Bruce Springsteen. The same logic that would disallow Springsteen's boilerplate agreement that his album is a work made for hire would seem to equally empower the backup musician to avoid the agreement that he had made to Springsteen.

Many intermediate results are possible, e.g., the saxophonist and singer are employees, but the mix engineer and producer are not. The further question arises whether the contribution of one employee's efforts renders the sound recording as a whole into a work-made-for-hire - or

1242000 Hearings, supra note 28, at 58 (statement of Hilary Rosen).

$1.25 \mathrm{Id}$. at 80 (statement of Michael Greene).

126 Id. at 43.

127 Id. at 116.

128 See supra note 115.

1292000 Hearings, supra note 28, at 68 (statement of Marci Hamilton) (emphasis added). 
could it be partially inside and partially outside that characterization? To revert to the work hypothesized above, in which a superstar performer collaborated with bona fide employees of record labels as sound engineers, ${ }^{130}$ what is the consequence? ${ }^{131}$ Three answers are possible:

- it is a work made for hire, given that part of its creation admittedly qualifies for that status;

- it is not a work made for hire, given that part of its creation admittedly does not qualify for that status;

- it is partially a work made for hire and partially not, given that some portions of it admittedly qualify under each of the prongs.

Which interpretation is to be preferred? The first two characterizations run roughshod over the status of various contributors. Faute de mieux, the third prong seems the only one viable. ${ }^{132}$ When courts are called to litigate the matter starting in 2003 , they may need to confront these riddles as well in trying to sort out whether individual songs and albums qualified as works made for hire.

130 See Part II[B][2] supra.

131 Early in the legislative process of the 1976 Act, one witness raised this matter: I do think that it's necessary from a drafting standpoint to clarify the position of a work such as a motion picture (and there are undoubtedly others) which represents the contributions of several or many creators, and where you do come out in the end with what I guess you'd call a unified work, one work, but to which the contributors may be employees, or may be specially commissioned, or may be people from whom you've bought something . . . I don't know who would own what. Perhaps there should be a separate category to cover 'composite works' - just to use a phrase temporarily - to cover that type of situation where not all of the contributors may have the same legal status.

Preliminary Draft for Revised U.S. Copyright Law, supra note 80, at 272. But Congress failed to act on that concern.

132 An analogy might help to illuminate this corner of the statute. Consider that statutory examples of "a supplementary work" eligible as "a work specially ordered or commissioned for use as a contribution to a collective work" include "forewords, afterwords, [and] pictorial illustrations." 17 U.S.C. $\S 101$ (2000). Now imagine that John Grisham writes his next novel, for which the publisher commissions $X$ to write an afterword and $Y$ to do the jacket art. The contributions of $\mathrm{X}$ and $\mathrm{Y}$ can be considered works made for hire, that of Grisham not. It would be perverse to consider the novel as a whole a work made for hire and to deny Grisham termination rights, just because he consented to the afterword and cover art. The first prong may therefore be rejected. The second makes no sense either - allowing $X$ and $Y$ to terminate their contributions thirty-five years down the pike on the supposition that the novel in its entirety fails to qualify as a work made for hire does violence to the inclusion of "afterwords, [and] pictorial illustrations" in the statute. Accordingly, the second prong must also be rejected. Accordingly, only the third prong makes sense. 
Again, as posed herein the various issues canvassed above arise in a vacuum. Only when an appreciable body of cases has litigated the issues will resolution emerge. In principle, though, it seems more than an idle possibility that "if it isn't a work for hire, then every creative participant on the album (like the producer, the arranger, the mix engineers, and each and every background musician and vocalist) would be a 'co-author' under the copyright law with an equal right to authorize the commercial use of that recording." 133 That result is baleful indeed - as the Register testified, "an unfettered termination right enjoyed by all performers and coauthors may well be unworkable and make many sound recordings unmarketable after 35 years." 134 Perhaps more accurately, such a situation may cause sound recordings to be "too" marketable - many people each possessing the right to license a work non-exclusively, subject only to a duty to account to co-owners.

The various considerations noted above call for detailed examination in the context of the history of how albums of sound recordings have historically been prepared. That matter, too, will form part of our follow-up article analyzing the status of attempted terminations rights in sound recordings. ${ }^{135}$

\section{EFFECT ON PUBLIC INTEREST}

Most glaring of all the matters missing at the 2000 Oversight Hearing was a broader sense of how the narrow issues on the table fit into the larger picture, to paraphrase the Constitution's Copyright Clause, of promoting the progress of the creative arts. ${ }^{136}$

\section{A. Beyond the Disputants}

Both parties at the 2000 Oversight Hearings boxed themselves into uncomfortable argumentative corners. ${ }^{137}$ Hilary Rosen testified on behalf of the RIAA, "We didn't seek this change because we thought it was necessary." 138 One wonders what the impetus for the change was, in that event. Michael Greene, testifying on behalf of the recording artists, had to admit that his organization "registered the 1998 Grammy CD in the Copy-

1332000 Hearings, supra note 28, at 118 (statement by head of the RIAA to Billboard Magazine).

134 Id. at 21.

135 See Defusing the Bomb, supra note 2.

136 U.S. CoNST. art. I, §8.

137 Cf. Sony Computer Entm't. Am., Inc. v. Bleem, LLC, 214 F.3d 1022, 1027 (9th Cir. 2000) (litigation posture "forces advocates into awkward argumentative corners").

1382000 Hearings, supra note 28 , at 81 . 
right Office as a work made for hire"139 - the very characterization which he purported to find indefensible when undertaken by the record companies.

Moving beyond the parochial concerns of those disputants, the larger goal of copyright law is to serve the public interest. ${ }^{140}$ The 2000 Oversight Hearings afforded Congress the opportunity to address the larger forces at work here, to craft copyright law in order to serve the public interest. Regardless of whether the statute's exclusion of sound recordings from the enumeration of specially commissioned works resulted in 1976 from inadvertence or design, ${ }^{141}$ Congress had the opportunity in 2000 to address the matter squarely.

Since 1976, motion pictures have always fallen inside the enumeration of specially commissioned works, whereas novels have always fallen outside. ${ }^{142}$ Sound recordings are collaborative works that are in some respects akin to motion pictures, but typically created with fewer contributors and smaller budgets, thereby in other respects resembling novels. When Congress decided to address the substantive issue via the 2000 Oversight Hearings, it squarely faced the policy judgment of exactly where along the spectrum to slot in sound recordings.

Numerous voices were heard asking Congress to "get it right" in 2000. But instead, Congress decided to shirk the larger issues and to express itself as neutrally as possible on the policy question of whether sound recordings should be subject to termination. As previously noted, the Copyright Act itself now contains language directing courts to pretend that the 1999 Amendment and 2000 Repeal "were never enacted, and without regard to any inaction or awareness by the Congress at any time of any judicial determinations." 143 Congress self-consciously ducked the "bitter and bloody fight" that would attend real resolution of the contentious issues

139 Id. at 93 . Note that Greene had a more plausible claim for classifying this phonorecord as a work made for hire (as a "contribution to a collective work") than, say, Warner Brothers' characterization of Jagged Little Pill as a work made for hire status on this basis: The Grammy CD collected various performances made at the awards presentation, whereas Alanis Morrisette's album arguably comprised a single cohesive work.

140 "The economic philosophy behind the [Constitution's] clause empowering Congress to grant patents and copyrights is the conviction that encouragement of individual effort by personal gain is the best way to advance public welfare through the talents of authors and inventors in 'Science and useful Arts." " Mazer v. Stein, 347 U.S. 201, 219 (1954).

141 See Part I[B] supra.

14217 U.S.C. $\$ 101$ (2000).

143 Id. (definition of "work made for hire"). 
underlying this domain. ${ }^{144}$ The matter therefore remains live for subsequent consideration. ${ }^{145}$

\section{B. Passions Unleashed}

Although the House Chair reaffirmed immediately prior to the 2000 repeal that "it was my belief that this [1999] amendment merely codified existing practice and that remains my belief," 146 even he conceded, in fairness to the other side, that "there is also ample and convincing authority that supports" the contrary viewpoint. ${ }^{147}$ Of course, others in Congress fell on the opposite side of the aisle, believing repeal necessary to "correct this injustice." 148

It is important to focus soberly on precisely what works are at issue in the debate. Given that the dispute revolves around the effect on sound recordings thirty-five years after their initial release, ${ }^{149}$ the vast number of records, even if successful, will have realized whatever potential they had long before that window is reached. In effect, it is only the "small number of highly successful works" that is even affected.150

Small impact does not, however, translate into little concern. To the contrary, a great deal of emotion surrounded the issue, with one congresswoman maintaining that the 1999 Amendment, if not repealed, "would have taken advantage of young artists who are not emotionally or financially prepared to sign their recording lives away." 151 As the Register testified, this issue "has stirred up passions beyond anything I could have imagined." 152

\section{Perverseness Triumphant}

There are passions and there are passions. In the musical realm, a record by Frans Brüggen, Kees Boeke, Walter van Hauwe goes by the name The Passion of Reason. It features fourteen tunes, beginning with Ma fin est mon commencement. As Guillaume de Machaut put it there, Mes tiers chans trois fois seulement. So in this third and final section, it is good to end back at the beginning, and to invoke the passion of reason.

\footnotetext{
1442000 Hearings, supra note 28, at 122 (statement of Rep. Berman).

145 See Defusing the Bomb, supra note 2.

146146 CoNG. ReC. H7244 (daily ed. Sept. 6, 2000) (statement of Rep. Coble).

147 Id.

148 See 146 Cong. Rec. H7773 (daily ed. Sept. 19, 2000) (statement of Rep. McCarthy).

149 See Part II[A] supra.

1502000 Hearings, supra note 28, at 66 (statement of Marci Hamilton).

151 See 146 Cong. Rec. H7773 (daily ed. Sept. 19, 2000) (statement of Rep. Bono).

1522000 Hearings, supra note 28, at 20 .
} 
Reason tells us that the device of termination of transfers - which, we have already seen, forms the nub of the are-sound-recordings-worksmade-for-hire? controversy ${ }^{153}$ - exists within the copyright realm to benefit individual creators. Congress originally explained its purpose for fashioning this device as "safeguarding authors against unremunerative transfers . . . needed because of the unequal bargaining position of authors, resulting in part from the impossibility of determining a work's prior value until it has been exploited." 154

More broadly, Congress included the device for termination of transfers in the 1976 Act because of the failure of a comparable device under the 1909 Act, which went by the name reversion of renewal rights. The problem with that feature of law was the way that the Supreme Court interpreted it:

The reversion of renewal rights was originally thought to afford struggling authors who parted with their works, often for a pittance, a second chance to enjoy the fruits of their labors at a later date. Though laudable in theory, this lofty goal was vitiated in practice by a ruling that an author who sells his copyright for the renewal term along with the original term loses copyright in both terms. ${ }^{155}$

The historical progression thus reveals that the largely ineffective "reversion of renewal" method of safeguarding impecunious artists of the 1909 Act yielded to the better vehicle under current law of "termination of transfers." How do the latter's concern regarding "the unequal bargaining position of authors" apply to the instant domain? As previously noted, the entire issue is live solely with respect to a "small number of highly successful works."156 In large part, those works stem from the superstars of the musical world.

Contrast the situation of new artist Jane Doe signing her first contract with a record label to that of Morrissette. Both will be presented with the industry boilerplate noted above designating their product as works made for hire. ${ }^{157}$ The former has no hope for deleting that provision; the latter might have the clout to be able to do so.

Now, consider how the 1999 Amendment (prior to the 2000 Repeal) allocates rights of the two. Its recognition of sound recordings as specially

153 See Part I[A] supra.

154 H.R. REP. No. 94-1476, at 124 (1976).

155 David Nimmer, United States, in INTERnational Copyright LaW and PraCTICE $§ 4[3][$ b] (1999) (citing Fred Fisher Music Co. v. M. Witmark \& Sons, 318 U.S. 643 (1943)).

156 See Part III[B] supra.

157 See Part I[C] supra. 
commissioned works means that Doe has parted with all rights to her song not only for thirty-five years, but for the entire term of copyright, after which the work enters the public domain. Morissette, by contrast, retains the right to terminate thirty-five years hence. As summarized by Rep. Howard Berman, the situation is wholly perverse:

So in effect, the artist with the clout not to have the work for hire provision in the contract is the artist who has the greatest sense of the value of the album, and the artist who doesn't have the clout to keep that out of the contract is the artist who most may really be needing the right of termination in 35 years because no one has compensated him for the possible big hit. ${ }^{158}$

As has happened so often before in the reversion and termination context, Congress failed to serve its self-stated goals of "safeguarding authors against unremunerative transfers." 159 For that reason, the 1999 amendment is out of kilter. But the 2000 repeal, by ducking the substantive issue, does not right the balance, either.

\section{Open Issues}

Sooner or later, therefore, courts will need to confront the question of who can terminate their contributions to sound recordings and who cannot. In effect, Congress enacted a scheme in 1976 whose effective date lay so far in the future that no one needed to work out the practical implications. That luxury has faded with the passage of time. With the imminent arrival of 2003,160 termination issues will soon become live. ${ }^{161}$

We defer until our later article an in-depth analysis of potential resolutions. ${ }^{162}$ For the nonce, it is instructive to focus on some aspects of copyright law which were not ventilated at the 2000 Oversight Hearings.

1582000 Hearings, supra note 28 , at 50 .

159 If transaction costs here were non-existent, then the market would presumably reallocate rights efficiently regardless of the party whom the statute treats as the first owner of the subject rights. See Ronald Coase, The Problem of Social Cost, 3 J. L. Econ. 1 (1960). But, of course, the market for music licensing is hardly frictionless, so the party in whom rights first vest is important, after all, not to mention the monkey wrench of inalienability. See supra note 61.

160 See Part II[A] supra.

161 A separate question is when they will become justiciable. As noted above, the first eligible time to send notices of terminations for works created in 1978 and thereafter is 2003; those terminations will themselves take effect in 2013. See Part II[A] supra. It remains to be seen whether live controversies will arise between concrete parties starting on the former date, or whether the matter will need to wait until the latter for resolution.

162 See Defusing the Bomb, supra note 2. 
1. Pro-featured artist doctrine. Let us return to the dismal prediction that "if it isn't a work for hire, then every creative participant on the album (like the producer, the arranger, the mix engineers, and each and every background musician and vocalist) would be a 'co-author' under the copyright law with an equal right to authorize the commercial use of that recording." 163 If realized, affected sound recordings would become "unmarketable." 164 To avoid reaching that dead end, the Copyright Office, it should be recalled, recommended focusing on the featured performer and other "key contributors" to the effort. ${ }^{165}$ Congress, however, failed to act on that recommendation.

Nonetheless, there is a possible vehicle to vindicate the rights of recording artists here in a manner consistent with the Copyright Office's recommendation of focusing on the featured performer, even absent implementing legislation. The road there passes through the parallel domain of motion pictures. When the appropriate writings are executed, audiovisual works can unambiguously qualify as specially commissioned works for hire. ${ }^{166}$ On occasion, however, that writing is lacking. The upshot would then seem to be that the non-covered contributors may qualify as joint authors of the affected film exactly like terminating featured artists, background vocalists, sound engineers, etc., would also qualify as joint owners following collective termination.

In Aalmuhammed v. Lee, ${ }^{167}$ decided several months before the 2000 Oversight Hearing, the Ninth Circuit confronted such a scenario in the film context. ${ }^{168}$ It ruled there that a minor contributor to the motion picture Malcolm $X$, who admittedly failed to sign the requisite writing, still lacked the status of joint "author" of the whole. ${ }^{169}$ From that conclusion,

163 See Part II[C] infra.

164 Id.

$165 I d$.

166 See 1 Nimmer \& Nimmer, supra note 6, § 5.03[B][2][a][i].

167202 F.3d 1227, 1238 (9th Cir. 2000). For an extended discussion of this case, see Dougherty, supra note 120.

168 Aalmuhammed is third of a trio of cases. In the first two, the Second Circuit determined that an actress/research assistant failed to qualify as joint author of a play about Jackie "Moms" Mabley; and that a dramaturge who added more than de minimis contributions to the play Rent nonetheless failed to qualify as its co-author. See Childress v. Taylor, 945 F.2d 500, 509 (2d Cir. 1991); Thomson v. Larson, 147 F.3d 195 (2d Cir. 1998). See generally David Nimmer, Copyright in the Dead Sea Scrolls, 38 Hous. L. Rev. 1, 186-87, 204-07 (2001) (deriving from that trio of cases principle of "intent to author").

169 See 1 Nimmer \& Nimmer, supra note $6, \S 6.07$ (discussing that trio of cases). 
it follows that the affected individual has no right to terminate. ${ }^{170} \mathrm{Al}-$ though no one cited Aalmuhammed at the Hearing, one way to apply it to the parallel scenario of sound recordings would be to determine that the only cognizable "authors" of sound recordings are their featured artists much in the way the Office recommended focus on the "key contributors." The result would be that Sheryl Crow and Bruce Springsteen could terminate and not be faced with umpteen other claimants to ownership of their sound recordings. ${ }^{171}$ That potential resolution should be borne in mind when a full-scale examination of how sound recordings are put together is undertaken. ${ }^{172}$

2. Pro-record company doctrine. The most often litigated aspect of the termination-of-transfer provisions of the 1976 Act is its Derivative Works Exception: ${ }^{173}$

A derivative work prepared under authority of the grant before its termination may continue to be utilized under the terms of the grant after its termination, but this privilege does not extend to the preparation after the termination of other derivative works based upon the copyrighted work covered by the terminated grant. ${ }^{174}$

Like the Aalmuhammed case mentioned above, no one at the 2000 Oversight Hearing discussed that Exception. But given that the whole controversy of whether sound recordings qualify as works made for hire arises out of the termination-of-transfer doctrine, ${ }^{175}$ all its aspects deserve scrutiny.

170 If those individuals never contributed copyrightable expression, then they failed to qualify as an "author" later entitled to terminate. See 17 U.S.C. $\S 203(\mathrm{a})(2000)$.

171 That pronouncement, it must be candidly admitted, relies on the same type of armchair speculation condemned above. In the real world, E Street Band members might contest Springsteen's claim to be the sole "key contributor" to their collective efforts. Crow might face similar claims. Accordingly, while this focus might significantly limit the number of claimants to ownership of termination rights, it will scarcely qualify as a bright line rule. Only Congress could have furnished the necessary specificity to reach that result, and it failed to act.

172 See Defusing the Bomb, supra note 2.

173 One of us has explored that matter at some length in these pages. See David Nimmer, Abend's Stepchild, 43 J. Copr. Soc'y 139 (1995). As discussed therein, some of the cases addressing this Exception are among the most convoluted in copyright law - and they rise all the way to the level of the United States Supreme Court.

17417 U.S.C. \& 203(b)(1) (2000).

175 See Part II[A] supra. 
One frequent pattern by which record albums are put together is to assemble thirteen pre-existing musical compositions and have a single artist perform each. That combination would seem easier to qualify as a "collective work" than is an album comprised of thirteen songs newly composed by the singer-songwriter for purposes of the album. For the former is composed of discrete elements, whereas the latter might be characterized as an integrated statement more analogous to a novel composed of discrete chapters. ${ }^{176}$ Thus, the record companies' primary heartburn arises as to the latter type of works.

As to those latter, an argument might lie that those same record companies can continue to exploit them under the Derivative Works Exception. Reverting to Alanis Morissette, to the extent that she both composed and performed the thirteen songs comprising Jagged Little Pill and granted rights therein to Warner Records in a single instrument, then her later termination of that 1995 agreement might fall within the language of the statute quoted above: It arguably relates to a "derivative work prepared under authority of the grant before its termination," in other words her recording [derivative work] of her song [underlying work].

Again, numerous issues of industry practice rise to the fore: How did Morissette and other artists assign their rights - in a single grant or separately as to music and performance? Can their grants be construed to relate to derivative works? Did they compose the music before entering into any relationship with the record company, or did they both compose and enter the recording booth as part of their contractual duties? Depending on the answers to these and similar questions, the record companies might have a basis to "continue to ... utilize [the affected recordings] under the terms of the grant after its termination." These matters also must be recalled in the context of the forthcoming detailed examination of how sound recordings and albums are put together. ${ }^{177}$

Even if the analysis unfolds such that record companies can ultimately claim the benefit of the Derivative Works Exception, the termination-oftransfers time bomb remains explosive. The Exception does not afford record labels the exclusive right to exploit sound recordings that they acquired thirty-five years ago. Rather, it merely allows them to continue to exploit such works and maintain the integrity of their catalogue. Recording artists who terminate would simultaneously be able to reproduce and distribute or license the right to reproduce and distribute the terminated work. The result would be to reduce record companies' profitability, likely resulting in renegotiation of rights in which the artist(s) gets a better

176 See Part II[B][2] supra.

177 See Defusing the Bomb, supra note 2. 
cut of the profits and more say in the exploitation of the work. That result might well effectuate the purposes underlying the termination-of-transfers provision; but it might not obtain in all cases and would likely necessitate significant transaction costs.

\section{FIN}

After two amendments to the Copyright Act, this domain remains up in the air. Ma fin est mon commencement. But that equilibrium is unstable. With 2003 looming, terminations will start to flow soon. The issues swept under the carpet at the 2000 Oversight Hearings will require resolution on their merits in the near future. Stay tuned for the next installment. 